\title{
Mechanical Properties and Fracture Behaviour of Coconut Fibre Reinforced Concrete (CFRC)
}

\author{
Amaziah Walter Otunyo ${ }^{1, *}$, Nnodi Dan Nyechieo ${ }^{2}$ \\ Department of Civil Engineering, Rivers State University, Nkpolu, Port Harcourt, Nigeria \\ *Corresponding author: umutuigili@yahoo.com
}

\begin{abstract}
The effect of coconut fibre content on the mechanical properties and fracture behavior of reinforced concrete was studied. The mix design used for the plain concrete and the coconut fibre reinforced concrete was based on 1:2:4 for cement: sand and coarse aggregate. Water/cement ratio used was 0.6. The coconut fibre was added as reinforcement principally to check the propagation of cracks. The composites developed by adding 6\%, $8 \%$, $10 \%$ and $12 \%$ coconut fibre (by weight), mixing and curing. Plain concrete was cats and cured and used as control. Composites were cured for 7, 14 and 28 days. It was observed that the composite with 6\% of coconut fibre demonstrated the highest compressive, flexural and split tensile strengths when compared to the control.
\end{abstract}

Keywords: coconut fibre, cement, concrete, compressive strength, flexural strength, split tensile strength, workability, slump

Cite This Article: Amaziah Walter Otunyo, and Nnodi Dan Nyechieo, "Mechanical Properties and Fracture Behaviour of Coconut Fibre Reinforced Concrete (CFRC)." American Journal of Civil Engineering and Architecture, vol. 5, no. 5 (2017): 208-216. doi: 10.12691/ajcea-5-5-5.

\section{Introduction}

Concrete primarily because of its low tensile strain capacity and fracture toughness is considered a brittle material.

Reinforcing concrete with fibres would not only improve on the compressive strength of concrete but also provide a significant improvement on the tensile strength, flexural strength, ductility, durability, toughness and also arrest cracks in concrete.

Several researchers have used plant fibres as an alternative of steel or synthetic fibres in composites such as cement paste, mortar and concrete [1-26].

These natural fibres include coconut, sisal, jute, hibiscus cannabinus, eucalyptus grandis pulp, malva, ramie bast, pineapple leaf, kenaf date, bamboo, palm, banana hemp, flax, cotton and sugarcane fibres [27].

Compared to stel fibres, they are also easy to use or handle because of their flexibility especially when high percentage of fibres is involved [27].

Coconut fibre is extracted from the outer shell of coconut. The common name, scientific name and plant family of coconut fibre are coir, cocos nucifera and arecaceae (palm), respectively. There are two types of coconut fibres, brown fibre extracted from matured coconuts and white fibres extracted from immature coconuts. Brown fibres are thick, string and have high abrasion resistance, while white fibres are smother and finer, but also weaker [27].

\subsection{Previous Works on Coconut Fibre Reinforced Composites}

Slate [11] investigated compressive and flexural strength of coconut fibre reinforced mortar. Two cement-sand ratios by weight 1:2.75 with water cement ratio of 0.54 and 1:4 with water cement ratio of 0.82 were considered. Fibre content was $0.08 \%$., $0.16 \%$ and $0.32 \%$ by total weight of cement, sand and water. The mortars for both design mixes without any fibres were also tested as reference. Cylinders of $50 \mathrm{~mm}$ diameter and $100 \mathrm{~mm}$ height and beams of $50 \mathrm{~mm}$ width, $50 \mathrm{~mm}$ depth and $200 \mathrm{~mm}$ length were tested. The curing was done for 8 days only. It was found that , compared to that of plain mortar of both mix designs, all strengths were increased in the case of fibre reinforced mortar with all considered fibre contents. However, a decrease in strength of mortar with an increase of fibre content was also observed.

Cook et. al. [12] reported the use of coconut fibre reinforced cement composites as low cost roofing materials. The parameters studied were fibre length $(2.5,3.75$ and $6.35 \mathrm{~cm})$, fibre volumes $(2.5 \%, 5,7.5 \%$, $10 \%$ and $15 \%$ ) and casting pressure (from 1 to $2 \mathrm{MPa}$ with an increment of $0.33 \mathrm{Mpa}$ ). They concluded that the optimum composite consisted of fibres with a length of $3.75 \mathrm{~cm}$, a fibre volume of fraction of $7.5 \%$ and is casted under the pressure of $1.67 \mathrm{MPa}$. A comparison revealed that this composite was much cheaper than locally available roofing materials. 
Aziz et. al. [13] cited the work of Das Gupta et. al. $[14,15]$ studied the mechanical properties of cement paste composites for different lengths and volume fractions of coconut fibres. Aziz et. al concluded that the tensile strength and modulus of rupture of cement paste increased when fibres up to $38 \mathrm{~mm}$ fibre length and $4 \%$ volume fraction were used. A further increase in length or volume fraction could reduce the strength of composite. The tensile strength of cement paste composite was 1.9, 2.5, 2.8, 2.2 and 1.5MPa when it was reinforced with $38 \mathrm{~mm}$ long coconut fibre and the volume fractions of $2 \%, 3 \%$, $4 \%, 5 \%$ and $6 \%$, respectively. The corresponding modulus of rupture was 3.6, 4.9, 5.45, 5.4 and 4.6MPa, respectively. $4 \%$ volume fraction of coconut fibres gave the highest mechanical properties amongst all tested cases. With 4\% volume fraction, they also studied the tensile strength of cement paste reinforced with different lengths of coconut fibres. With the fibre lengths of, 2.5, 3.8 and 2.7 $\mathrm{MPa}$, respectively. The results indicated that coconut fibres with a length of $38 \mathrm{~mm}$ and a volume fraction of $4 \%$ gave the maximum strength.

Paramasivam et. al [16] conducted a feasibility study of coconut fibre reinforced corrugated slabs of $915 \mathrm{~mm}$ x460mm x 10mm for low-cost housing. A cement-sand ratio of 1:0.5 and water-cement ratio of 0.35 were used. Test for flexural strength using third point loading was performed. For producing required slabs having a flexural strength of $22 \mathrm{MPa}$, a fibre length of $2.5 \mathrm{~cm}$, a volume fraction of $3 \%$, and a casting pressure of $0.15 \mathrm{MPa}$ were recommended. The thermal conductivity and absorption coefficient for low frequency sound were comparable with those of asbestos boards.

Agopyan et. al. [17] studied coir and sisal fibres as replacement of asbestos in roofing tiles. The dimensions of the tiles were $487 \mathrm{~mm} \times 263 \mathrm{~mm} \times 6 \mathrm{~mm}$. Three-point bend test specimen with $2 \%$ total fibre volume fraction, support span of $350 \mathrm{~mm}$, deflection rate of $3 \mathrm{~mm} / \mathrm{min}$ was employed for determination of the maximum load. After the ageing periods of 16 and 60 months, the corresponding maximum load taken by coir tile were 235 and 248N., respectively while that by sisal tiles were 237 and 159n, respectively. The major benefit of reinforced tiles was their at least $22 \%$ higher energy absorption than that of the unreinforced tiles which could help to avoid fragile rupture of tiles during transportation or installation.

John et al [18] studied the coir fibre reinforced low alkaline cement mortar taken from the internal and external walls of a 12 year old house. The panel of the house was produced using 1:1.5:0.504 (cement:sand:water), by mass) mortar reinforced with $2 \%$ of coconut fibres by volume. Fibres removed from the old samples were reported to be undamaged. No significant difference was found in the lignin content of fibres removed from external and internal walls, confirming the durability of coconut fibres in cement composites.

Luisito et al [19] of PCA-Zamboagana Research Centre in Philippines invented coconut fibre boards (CFB) for applications such as tiles, bricks, plywood and hollow blocks. It is used for internal and exterior walls, partitions and ceiling. CFB consisted of 70\% cement and 30\% fibre by weight. It has water absorption of $32 \%$, water swelling of $4.2 \%$ and bending strength of $0.81 \mathrm{MPa}$, respectively.
Mohammad [20] tested wall panels made of gypsum and cement as binder and coconut fibre as reinforcement. Bending and compressive strength, moisture content, density and water absorption were investigated. As expected, coconut fibres did not contribute to bending strength of the tested wall panels. Compressive strength increased with the addition of coconut fibres. There was no considerable change of moisture content with coconut fibres. However, moisture content increased with time. Water absorption of panels was not significantly affected with an increase in fibre content.

Ramakrishna and Sundararajan [21] carried out the experiments ion impact resistance of slabs using falling weight of $0.475 \mathrm{~kg}$ from a height of $200 \mathrm{~mm}$. The slabs consisted of 1:3 cement-sand mortar with the dimension of $300 \mathrm{~mm} \times 300 \mathrm{~mm} \times 20 \mathrm{~mm}$. They were reinforced with coconut, sisal, jute and hibiscus cannabinus fibres having four different fibre contents of $0.5 \%, 1.0 \%, 1.5 \%$ and $2.5 \%$ by weight of cement and three fibre lengths of 20 , 30 and $40 \mathrm{~mm}$. A fibre content of $2 \%$ and a fibre content of $40 \mathrm{~mm}$ of coconut fibre showed the best performance by absorbing 253.5J impact energy. At ultimate failure all fibres except coconut fibre, showed fibre fracture while coconut fibre showed fibre pull-out. The ultimate failure was determined based on the number of blows required to open a crack through the entire length of the specimen.

$\mathrm{Li}$ et al [22] studied untreated and alkalized coconut fibres with the lengths of $20 \mathrm{~mm}$ and $40 \mathrm{~mm}$ as reinforcement in cementitious composites. Mortar was mixed in a laboratory mixer at a constant speed of $30 \mathrm{rpm}$, with cement: sand: water::super plasticizer ratio of 1:3:0.43:0.01 by weight, and fibres were slowly put into the running mixer. The resulting mortar had a better flexural strength (increased up to 12\%)., higher energy absorption ability (up to $1680 \%$ ) and a higher ductility (up to $1740 \%$ ), and is lighter than the conventional mortar.

Reis [23] performed third-point loading tests to investigate the flexural strength, fracture toughness and fracture energy of epoxy polymer concrete reinforced with coconut, sugarcane bagasse and banana fibres. The investigation revealed that fracture toughness and energy of coconut fibre reinforced polymer concrete were the highest, and an increase of flexural strength up to $25 \%$ was observed with coconut fibres.

Asasutjarit et al [24] determined the physical (density, moisture content, water absorption and thickness swelling), mechanical (modulus of elasticity, modulus of rupture and internal bond) and thermal properties of coir-based light weight cement board after 28 days of hydration. The physical and mechanical properties were measured by Japanese Industrial Standard JIS a 5908-1994 and the thermal properties according to JIS R 2618. The parameters studied were fibre length, coir pre-treatment and mixture ratio. $6 \mathrm{~cm}$ long boiled and washed fibres with optimum cement:fibre:water weight ratio of 2:1:2 gave the highest modulus of rupture and internal bond amongst the tested specimens. The board also had a thermal conductivity lower than other commercial flake board composite.

Buruah and Talukdar [25] investigated the mechanical properties of plain concrete (PC) and fibre reinforced concrete (FRC) with different fibre volume fractions 
ranging from $0.5 \%$ to $2 \%$. Steel, synthetic jute and coconut fibres were used. Here the discussion is limited to the coconut fibres reinforced concrete (CFRC) only. The cement:sand:aggregate ratio for plain concrete was 0.535 . Coconut fibres having length of $4 \mathrm{~cm}$ and an average diameter of $0.4 \mathrm{~mm}$ with volume fraction of $0.5 \%$., $1 \%$, $1.5 \%$ and $2 \%$ were added to prepare CFRC. The sizes of of specimens were (1) $150 \mathrm{~mm}$ depth and 300mm height for cylinders (2) $150 \mathrm{~mm}$ width, $150 \mathrm{~mm}$ depth and $700 \mathrm{~mm}$ length for beams, and (3) $150 \mathrm{~mm}$ cubes having a cut of $90 \mathrm{~mm} \times 60 \mathrm{~mm}$ in cross-section and $150 \mathrm{~mm}$ high for L-shaped shear test specimens. All specimens were cured for 28 days. The compressive strength q, splitting tensile strength (STS), modulus of rupture (MOR) using four point load test and shear strength $\mathrm{T}$. It can be seen that CFRC with $2 \%$ fibdres showed the best overall performance amongst all volume fractions. The compressive strength, splitting tensile strength, modulus of rupture and shear strength of coir fibre reinforced concrete withy $2 \%$ fibres by volume fraction were increased up to $13.7 \%$, $22.9 \%$, $28.0 \%$ and $32.7 \%$, respectively as compared to those of plain concrete. Their research indicated that all these properties were improved as well for CFRC with other fibre volume fractions of $0.5 \%, 1 \%$ and $1.5 \%$. Even for CFRC with small fibre volume fraction of $0.5 \%$ the corresponding properties were increased up to $1.3 \%, 4.9 \%$, $4.0 \%$ and $4.7 \%$, respectively.

$\mathrm{Li}$ et al [26] studied fibre volume fraction and fibre surface treatment with a wetting agent for coir mesh reinforced mortar using nonwoven coir mesh matting. They performed a four-point bending test and concluded that cementitious composites, reinforced by three layers of coir mesh with a low fibre content of $1.8 \%$, resulted in a $40 \%$ improvement in the maximum flexural strength. The composites were 25 times stronger in flexural toughness and about 20 times higher in flexural ductility.

To the best knowledge of the authors the only research [25] on the static CFRC properties is done with only one coir fibre length of $4 \mathrm{~cm}$. With regard to dynamic properties of CFRC, no study has been reported. Dynamic tests had been performed only for concrete reinforced by other fibres, e.g. polyolefin fibres [37] or rubber scrap [38]. To reveal the consequence of fibre lengths and other parameters are required in order to have reliable insights. To be able to apply CFRC in cheap housing in tropical earthquake regions, the knowledge of static and dynamic properties of CFRC is necessary.

Spadea, et al [28] investigated the strength and ductility properties of recycled PET fibre-reinforced concrete (RPETFRC) with different mix design and PET filaments with variable mechanical geometric properties. Tests highlighted that the most relevant effect of the recycled PET for reinforced fibre concrete are concerned with matrial toughness and ductility.. In the case of strength test, significant compressive and flexural strength enhancements due to the addition of PET fibre are noticed..

Ali [29] studied the role of post-tensioned coconut-fibre ropes in mortar-free interlocking concrete construction during seismic loadings. It was observed that there is a percentage difference up to $35 \%$ in predicting the structures response which can be attributed towards the complicated nature of the structure versus the simple approach developed. This can be of help in understudying the behavior of mortar-free interlocking structure having post-tension coconut-fibre rope in a systemic manner.

Wang et al [30] investigated the behavior of coconut fibre reinforced concrete (CFRC) under impact loading. This was with a view to prevent the damage resulting from impact loading and developing mitigating measures. Results from their experimental work showed that CFRC can absorb more impact energy tha, while plain concrete shows brittle failure. The study also defined the influence factors that control the energy dissipation of the composite which will be used for for developing future protection structures in earthquake regions.

Lumingkewas et al [31] carried out a study on the effect of fibres length and fibres content on the splitting tensile strength of coconut fibres reinforced concrete composite. They used fibre content of $(1,2,3$ and $4 \%$ by mass ratio of fibre per cement and the length of fibres (5, 20 and, $40 \mathrm{~mm}$ ) in the concrete. The results show that coconut fibre length of $5 \mathrm{~mm}$ and fibre content of of $3 \%$ in fibre concrete composite gave the composite 1.28 times higher splitting tensile strength than plain concrete. The density of the fibre concrete composite, decreases with the addition of coconut fibre content.

Prasad et al [32] investigated self compacting concrete beams strengthened with natural fibre undr cyclic loading. They concluded that coconut fibre has the highest toughness amongst all fibres. A comparison was made between the cyclic and static loading of coconut fibre reinforced self compacting concrete. It was observed that (FRSCC) members from the test data obtained, hysteresislogs were obtained, same as comparison of envelope curve, energy dissipation, stiffness degradation to justify the use of coconut fibre in slef compacting concrete.

An observation of the literature review above revealed that weight fraction and volume fraction of the coconut fibre added to the concrete was between (1-6\%). This study was carried out using 6\%, $8 \%, 10 \%$ and $12 \%$ weight fraction of coconut fibre.The gap being filled in this study is primarily in the area of increased coconut fibre content. Coconut fibre is an agricultural waste which is readily available in Nigeria.. Its use to improve the mechanical properties and fracture behavior of reinforced concrete will be of immense benefit in the environmental protection as well as an economic gain in the cost of production of reinforced concrete that could conveniently withstand crack propagation.

\section{Materials and Methods}

\subsection{Materials}

\subsubsection{Cement}

Ordinary Portland Cement (OPC) manufactured by DANGOTE INDUSTRIES Plc was used The cement used in the study was (Grade 42.5). It conformed to [33].

\subsubsection{Fine Aggregate}

Naturally occurring river sand obtained from Imo River in Oyigbo Local Government Area of Rivers State was 
used. The maximum size was $4.75 \mathrm{~mm}$. Impurities were removed and it conformed to the requirements of [34].

\subsubsection{Coarse Aggregate}

Coarse aggregate used is crushed angular and rough textured granite obtained from CRUSHED ROCK INDUSTRIES Plc at Isghiagu io Ebonyi State, South Eastern Nigeria. Maximum size was $20 \mathrm{~mm}$. It conformed to [34].

\subsubsection{Coconut Fibre}

The coconut fibre used for the project was obtained locally in Port Harcourt from local coconut traders. The fibres are usually obtained by manually extracting them from the outer coconut fruit shell. The fibres were washed properly to remove films of impurities attached to them, after which they were air dried for some few days under ambient temperature. The fibres were cut using scissors to lengths of approximately $25 \mathrm{~mm}$

\subsubsection{Water}

Potable water used was obtained from the Civil Engineering Laboratory of the Rivers State University, Port Harcourt The water conformed to [35].

\subsection{Method}

Fibre lengths of $25 \mathrm{~mm}$ and $0.03 \mathrm{~mm}$ diameter and fibre contents by weight of cement of $0 \%, 6 \%, 8 \%, 10 \%$ and $12 \%$ were considered for the investigation. Of the mechanical properties and fracture behavior of CFRC.

\subsubsection{Laboratory Preparation of the Coconut Fibre and Coconut Fibre Reinforced Cement}

The CFRC used had constituent materials made of fine and coarse aggregates, OPC, water and coconut fibre. The coconut fibres were washed, dried and cut into sizes of $25 \mathrm{~mm}$ length and $0.03 \mathrm{~mm}$ diameter. The arrangement of the fibres in the concrete is still a subject of controversy in the sense that the fibres cannot be expected to remain straight in the concrete cubes during mixing, casting and curing.. The random distribution of the fibers and their ability to add strength and mitigate crack propagation is more important. Coarse aggregates were $5 \mathrm{~mm}$ or larger in size, while fine aggregates were less than $5 \mathrm{~mm}$ in size.

Concrete cubes, beams and cylinders were prepared of sizes $150 \mathrm{~mm} \times 150 \mathrm{~mm} \times 150 \mathrm{~mm}, 100 \mathrm{~mm} \times 100 \mathrm{~mm} \times$ $500 \mathrm{~mm}$ and $150 \mathrm{~mm} \times 300 \mathrm{~mm}$ respectively. They were cast for the plain concrete as well as for the CFRFC. Preparation of the CFRC was done in accordance with [27], as stated as follows.. A layer of coconut fibre was spread in the pan, followed by spreading of aggregate, sand and cement. The first layer of fibres was hidden under the dry concrete materials with the help of a spade. Then, another layer of coconut fibre followed by layers of aggregate, sand and cement was spread. This process is repeated until the rest materials were put into the mixer pan. Approximately three quarters of the water (according to water/cement ratio which was the same as that of plain concrete) was added and the mixer was rotated for $2 \mathrm{~min}$. All the cast specimens were given a 24 hour period to set under ambient temperature in their respective moulds before being transferred to a curing tank for the appropriate curing days to their final tests.

\subsubsection{Mix Design of the CFRC}

The control was plain concrete. The mix design ration for cement:sand:aggregate was 1:2:4 respectively, while the water cement ratio was 0.6 . The same mix ratio and water cement ratio was used for the CFRC. The various constituents of the CFRC fine aggregate, coarse aggregates, water and coconut fibre were calculated by mass of cement.

\subsubsection{Particle Size Distribution Test}

The particle size distribution of both fine and coarse aggregates was carried out in accordance with [36].

\subsubsection{Compressive Strength}

Compressive strength test was carried out at 7,14 and 28 days for CFRC cubes in accordance with [37]. For each replacement level, 3 cubes were prepared, cured and crushed and the average value of the 3 results was used.

\subsubsection{Flexural Strength}

The flexural strength tests was carried out of plain beam CFRC specimens of size $100 \mathrm{~mm} \mathrm{x} \mathrm{100mm} x$ $500 \mathrm{~mm}$ loaded at one- third of its length from the extreme sides. Equal loads were applied at these points from sides of the beam support and an equal reaction is induced also. The flexural strengths were determined at 7, 14 and 28days. The test was performed in accordance with [38].

\subsubsection{Split Tensile Strength}

The split Tensile strength was carried out with cylindrical specimens measuring 150mm (dia) and 300mm (length). The split tensile strength was determined at 7, 14 and 28 days in accordance with [39].

\subsubsection{Setting Time}

The initial and final setting times of the specimen cubes with $0 \%, 6 \%, 8 \%, 10 \%$ and $12 \%$ were carried out in accordance with [40].

\subsubsection{Workability}

The workability of fresh concrete determines the ease with which it can be mixed, placed and transferred into its final location and compacted. The slump of the CFRC with, $0 \%, 6 \%, 8 \%, 10 \%$ and $12 \%$ were determined in accordance with [41].

\section{Results and Discussion}

\subsection{Particle Size Distribution}

The particle size distributions of the coarse and fine aggregates are shown in Figure 1 and Figure 2. These charts show the behavioral pattern of the varied aggregate sizes, It can be observed that for the coarse aggregate size, the envelope for the coarse aggregate was that of the nominal size and for the fine aggregates the distribution is within the sand zone. 


\section{PARTICLE SIZE DISTRIBUTION CURVE}

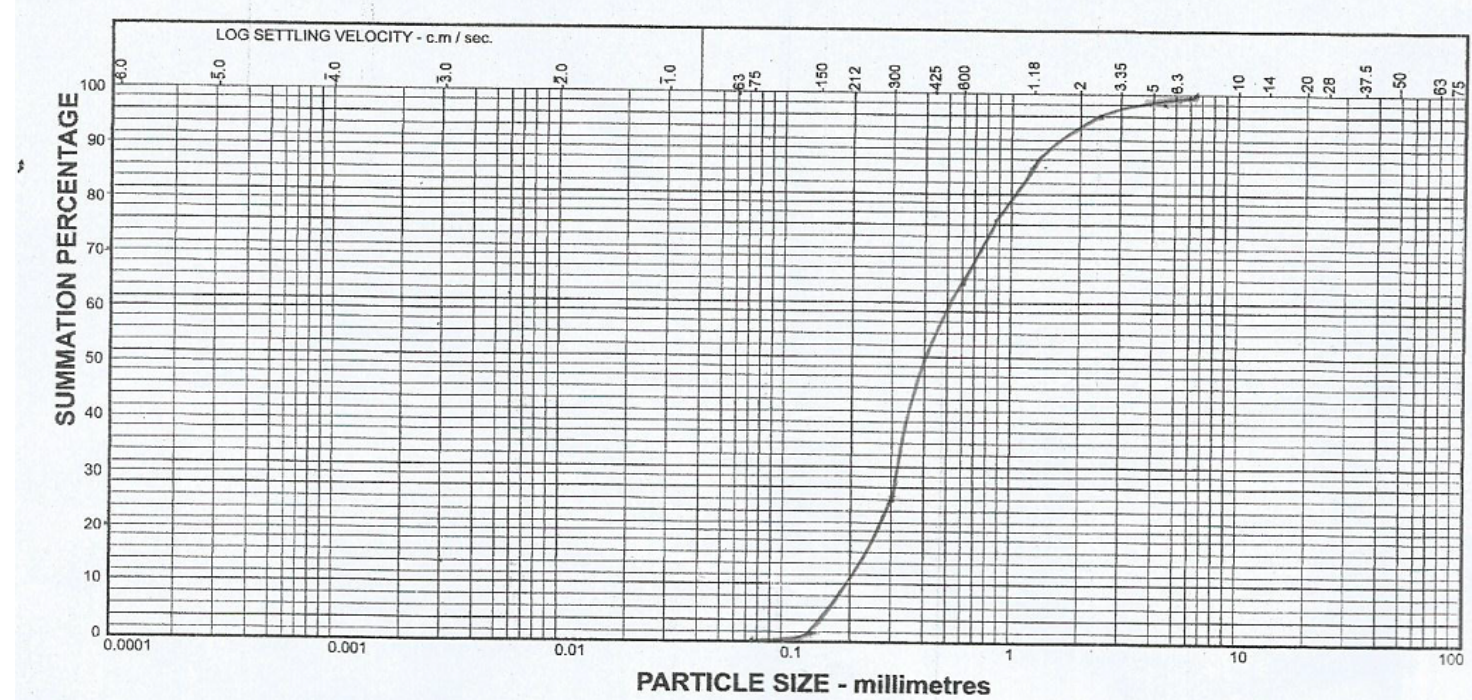

Figure 1. Particle Size Distribution for Fine Aggregates

\section{PARTICLE SIZE DISTRIBUTION CURVE}

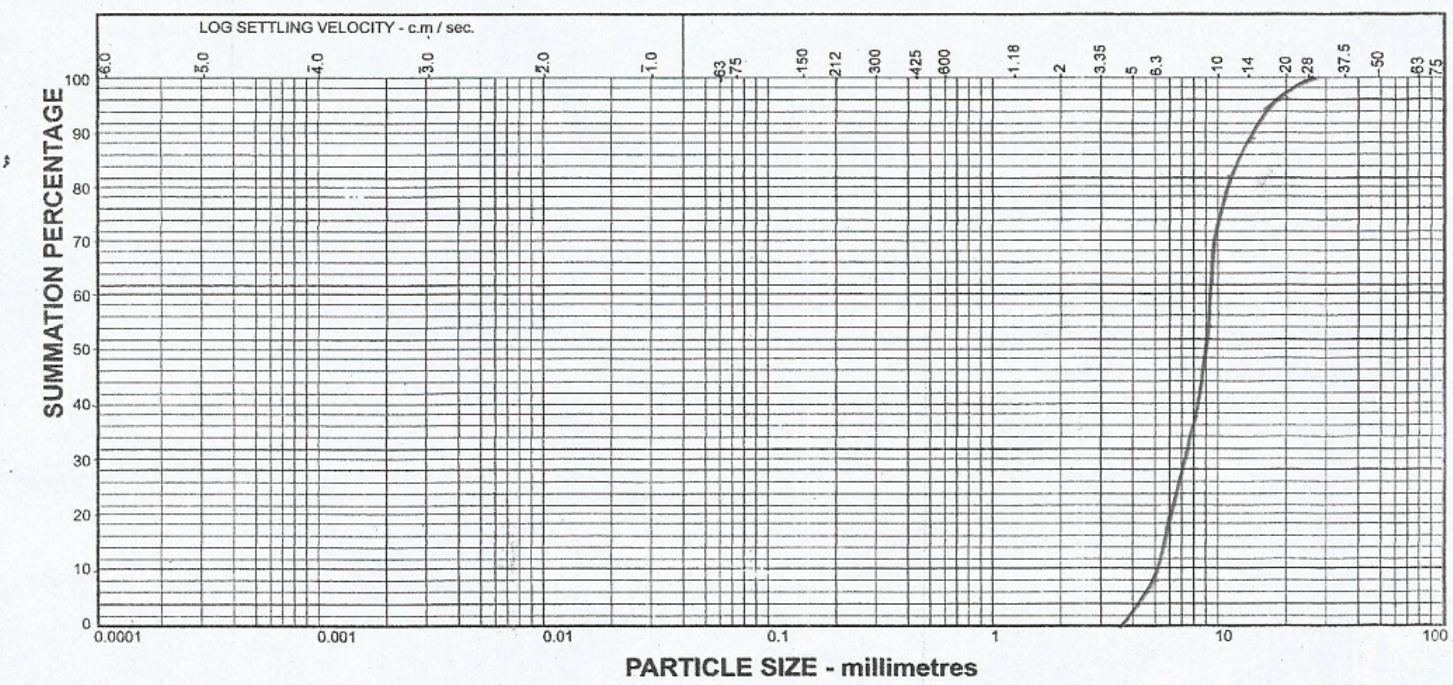

Figure 2. Particle Size Distribution for Coarse Aggregate

\subsection{Compressive Strength}

Figure 3 shows the the plot of the compressive strength at 7, 14 and 28 days for CFRC with coconut fibre content of $0 \%, 6 \%, 8 \%, 10 \%$, and $12 \%$. In all cases, the compressive strength decreased as the quantity of the coconut fibre was increased. However, it is important to point out that up till $6 \%$ coconut fibre content, the compressive strength achieved for the 7, 14 and 28 days was not remarkably different from that of normal plain concrete, $\left(21.0 \mathrm{~N} / \mathrm{mm}^{2}, 22.22 \mathrm{~N} / \mathrm{mm}^{2}\right.$ and $23, .77 \mathrm{~N} / \mathrm{mm}^{2}$ ) for 7, 14 and 28 days. Since the coconut fibre assisted in resisting cracks, it could be safely stated that a maximum of $6 \%$ coconut fibre content added to concrete will resist crack propagation and still produce adequate compressive strength. The decrease in compressive strength as the content iof coconut fibre is increased is due to the resistance provided by the fibre via their surface areas and rigidity offered to the stresses induced in the walls [27].

\subsection{Flexural Strength}

Figure 4 shows a plot of the flexural strength of the CRFC against the percentage of the coconut fibre content. The result is a mirror image of that of the compressive strength. Flexural strength decreased as the content of the coconut fibre in the CFRC was increased. Similarly, up till $6 \%$ coconut fibre content, there was no appreciable decrease in flexural strength at 7, 14 and 28 days when compared to the plain concrete. Flexural strength at $6 \%$ coconut fibre content was $\left(6.0 \mathrm{~N} / \mathrm{mm}^{2}, 8.3 \mathrm{~N} / \mathrm{mm}^{2}\right.$ and $\left.10.5 \mathrm{~N} / \mathrm{mm}^{2}\right)$ as against values of $\left(7.0 \mathrm{~N} / \mathrm{mm}^{2}, 9.0 \mathrm{~N} / \mathrm{mm}^{2}\right.$ and $12.0 \mathrm{~N} / \mathrm{mm}^{2}$ ) for $0 \%$ coconut fibre content at 7,14 , and 28 Days respectively.

The bond strength between fibres and the concrete ingredients was not very efficient and as such the tensile stress could not be resisted, in addition to this, the fibre was rather too flexible to resist the bending stresses [27]. 


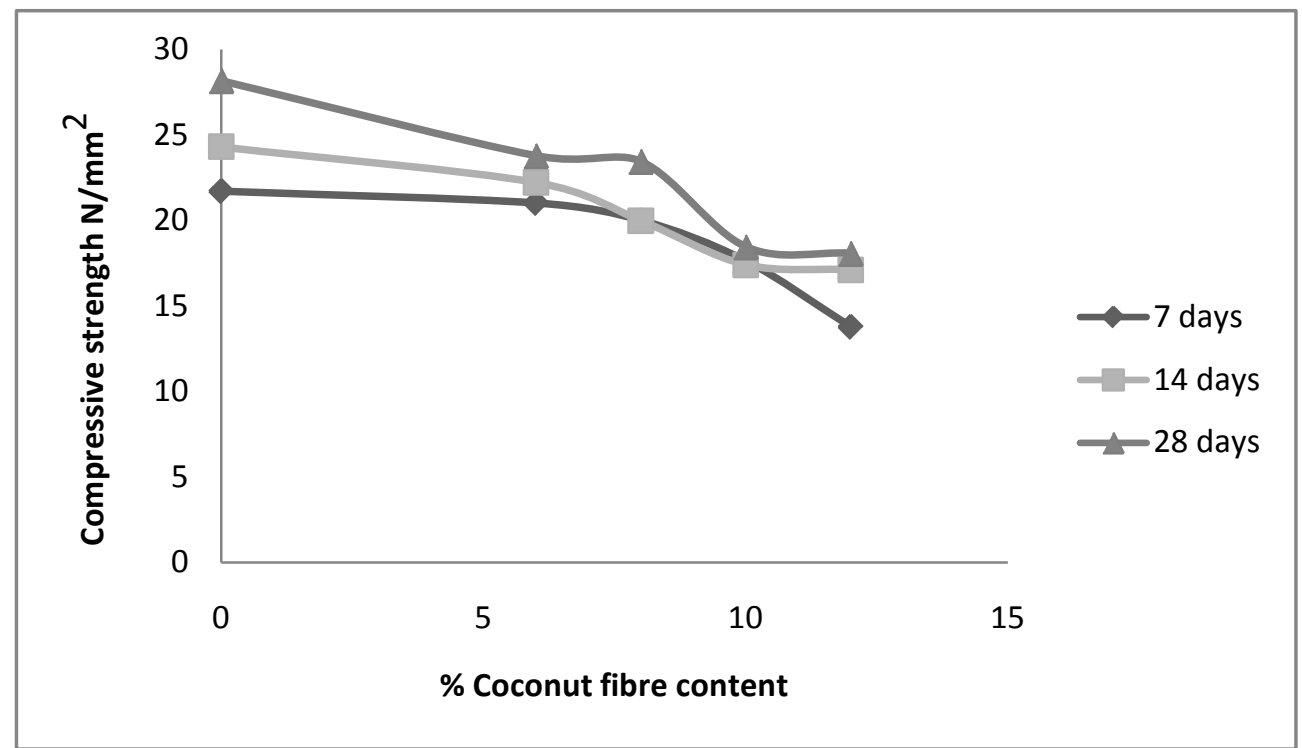

Figure 3. Compressive strength versus percentage coconut fibre

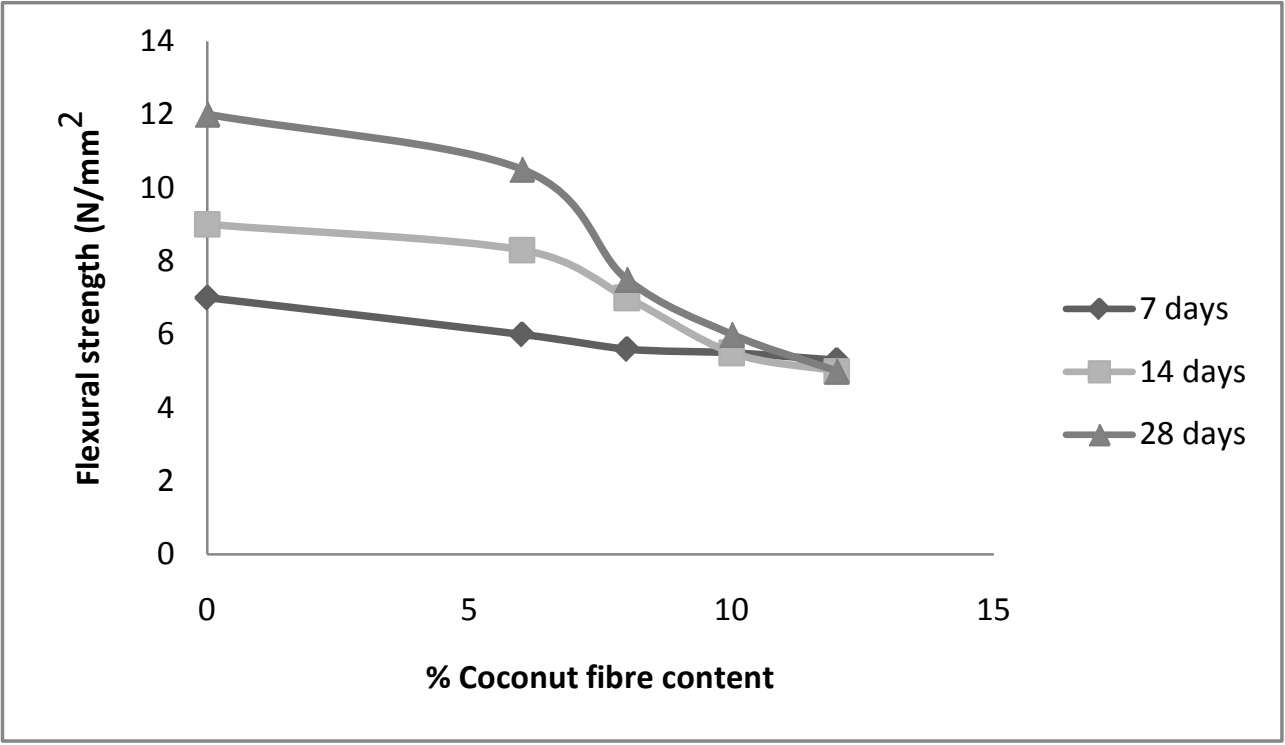

Figure 4. Flexural strength versus percentage of coconut fibre content

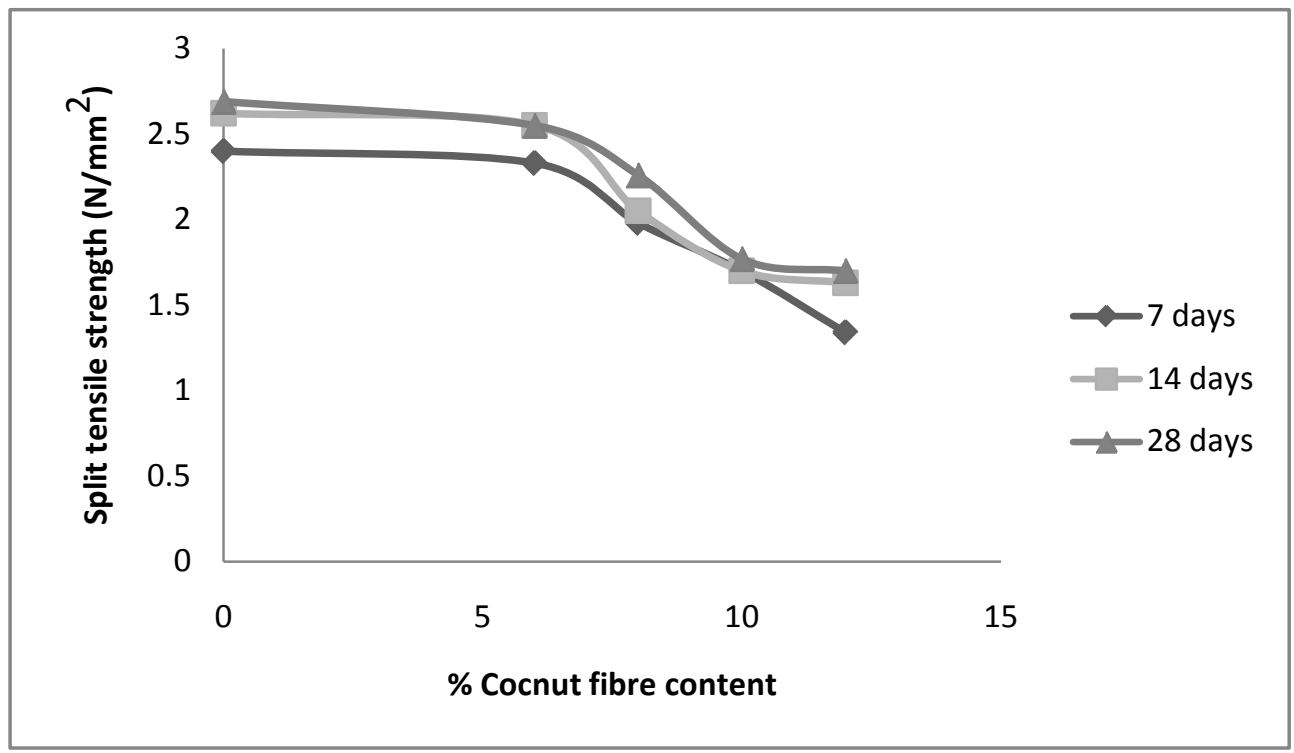

Figure 5. Split tensile strength versus coconut fibre content 


\subsection{Split Tensile Strength}

The trend of reduction noticed in the compressive and flexural strength was also noticed in the split tensile strength result as can be observed from Figure 5. The same reason adduced for the compressive and flexural strength is applicable.

Up till 6\% coconut fibre content split tensile strength of $\left(2.33 \mathrm{~N} / \mathrm{mm}^{2}, 2.55 \mathrm{~N} / \mathrm{mm}^{2}\right.$ and $\left.2.55 \mathrm{~N} / \mathrm{mm}^{2}\right)$ were obtained as against $\left(2.40 \mathrm{~N} / \mathrm{mm}^{2}, 2.62 \mathrm{~N} / \mathrm{mm}^{2}\right.$ and $\left.2.69 \mathrm{~N} / \mathrm{mm}^{2}\right)$ for $0 \%$ coconut fibre content at 7,14 and 28 days respectively. There is no appreciable different in split tensile strength between $0 \%$ and $6 \%$ coconut fibre content in concrete.

\subsection{Setting Time}

Figure 6 is a graph of the setting time against the CFRC with varying percentages of coconut fibre. The initial and final setting times decreased as the content of the coconut fibre is increased. As in other properties, up till 6\%, there was no change in setting time between the plain concrete and CFRC. The addition of fibre reduces the hydration process and as such both plastic and solid state were attained faster by the concrete.

\subsection{Workability}

Figure 7 is a plot of the slump values in (mm) against the percentage of coconut fibre. The workability decreased as the quantity of the coconut fibre increases. The rate of water absorption increases with increasing content of the coconut fibre. At $12 \%$ coconut fibre, the lowest slump value of $3 \mathrm{~mm}$ was observed.

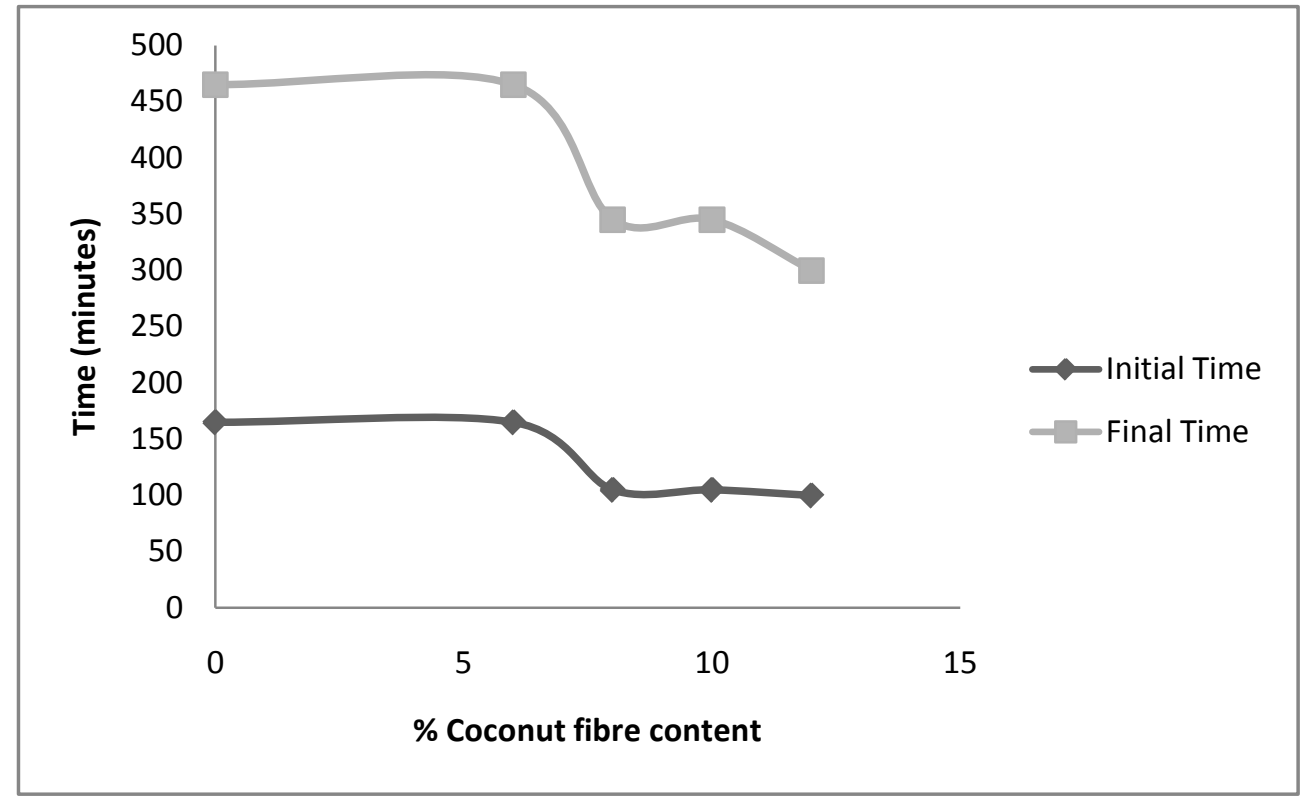

Figure 6. Setting time versus percentage coconut fibre content

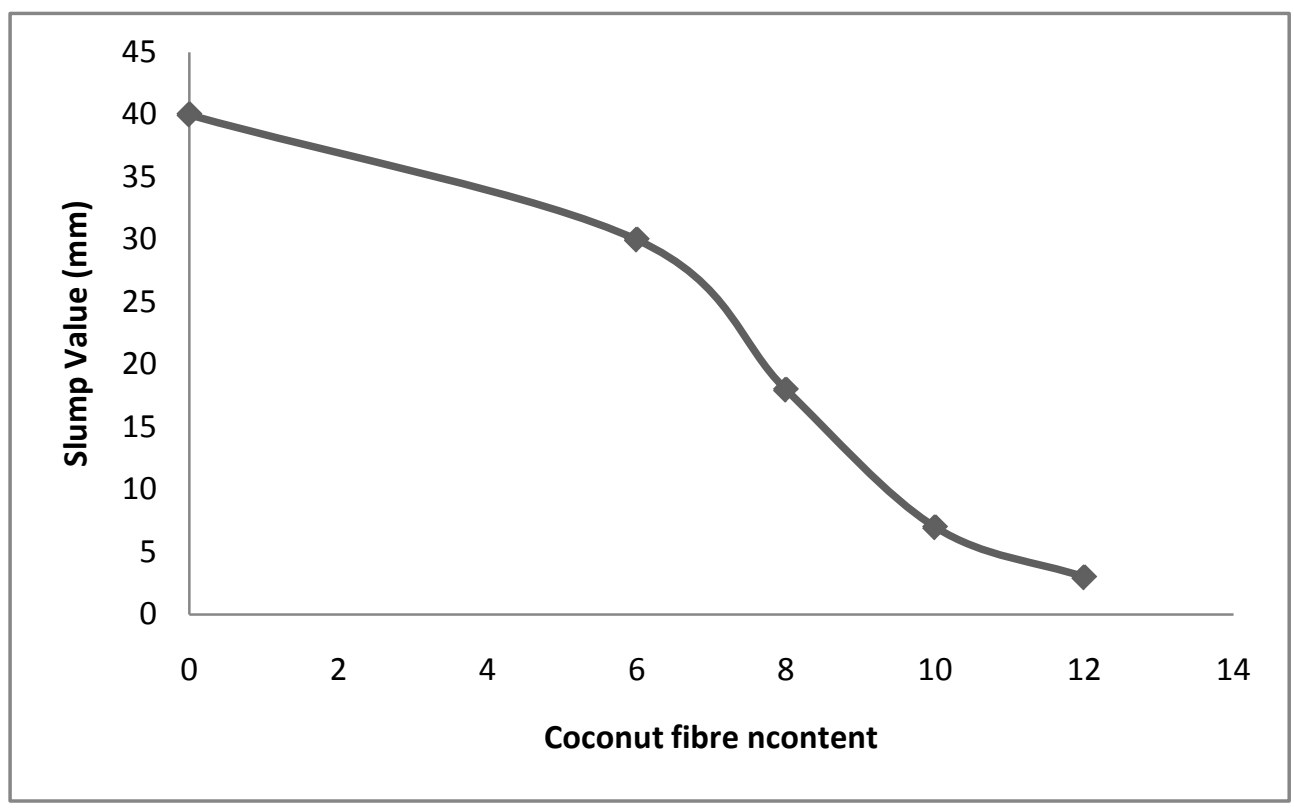

Figure 7. Slump value (mm) versus percentage coconut content 


\section{Conclusion}

The following conclusions were drawn from the result of the experiments.

(i) The compressive, flexural, split tensile strength, workability and setting time decreased as the coconut fibre content was increased in the CFRC.

(ii) Up till 6\% coconut fibre content there was no appreciable change in the values of the compressive, flexural, split tensile strength, workability and setting time. It can therefore be concluded that the optimum coconut fibre content to produce concrete with strength values close to normal plain concrete but with ability to resist crack propagation is $6 \%$ of coconut fibre content.

(iii) $6 \%$ coconut fibre in concrete can act as an admixture (accelerator) while still retaining compressive, flexural and split tensile strength comparable to those of normal concrete.

\section{Abbreviations}

BS - British Standard

CFB - Concrete Fibre Board

CRCF - Coconut Fibre Reinforced Concrete

FRC - Fibre Reinforced Concrete

FRSCC - Fibre Reinforced Self Compacting Concrete

MOR - Modulus of Rupture

OPC - Ordinary Portland Cement

PC - Plain Concrete

PET - Polyethylene Teraphthalate

RPETFRC - Recycled PET Fibre Reinforced Concrete. STS - Split Tensile Strength

\section{References}

[1] L.K. Aggarwal, "Studies on cement-bonded coir fibre boards," Cem .Concr. Composite., Vol. 14. No. 1, pp. 63-72, 1992.

[2] S.K, Al-Oraimi, and A.C. Seibi, "Mechanical characterization and impact behavior of concrete reinforced with natural fibres", Compos Struct, Vol. 32, No. 1, pp 164-71, 1995.

[3] M. A. Aziz, P. Paramasivam, S.L.Lee, "Concrete reinforced with natural fibres”, New Reinf. Concr, pp 106-40, 1984.

[4] E. Corradini, I.C. De Morais, M.F. De Rosa, S. E. Mazetto, L.H.C. Mattoso, J.A.M. Agnelli, "A Preliminary study for the use of of natural fibres as reinforcement in starch-gluten-glycerol matrix,” Macromol Symp, pp. 245-246; 558-622, 2006.

[5] J.E.Fernandez, "Flax Fibre reinforced concrete - a natural fibre biocomposite for sustainable building materials," High Perform Structural Material, Vol. 4, pp. 193-207, 2002.

[6] P.A. Flower, J.M. Hughes and R. Melias, "Review bio composites: technology environmental credentials and market forces,”. Journal of Science Food Agric; Vol. 86, pp. 1781-1790, 2006.

[7] B.I.M Mwamila, "Natural twines as main reinforcements in concrete beams,” International Journal of Cement and Lightweight Concrete, Vol. 7, No. 1, pp.11-20, 1985.

[8] H.S. Ramaswamy, B. M. Ahuja, S. Krishamoorthy, "Behaviour of concrete reinforced with jute, coir and bamboo fibres," International Journal of Cement Composites Lightweight concrete, Vol. 5, No.1, pp. 3-13, 1983.

[9] K.M.M Rao,K.M Rao, "Extraction and tensile properties of natural fibres: vakka date and bamboo.” Composite Structure, Vol. 77, No. 3, pp. 288-383, 2007.

[10] F.R.D Toledo, K. Ghavami, and G.IEngland, "Free restrained and drying shrinkage of cement mortar composites reinforced with vegetable fibres.” Cement Concrete Composite, Vol. 27, No. 5, pp. 537-4563, 2005.
[11] F.O. Slate, "Coconut fibres in concrete, "Engineering Journal Singapore, Vol. 3, No.1; pp. 51-55, 1976.

[12] D.J Cook, R.P. Pama, and H.L.S.D Weerasingle, “Concrete Fibre reinforced cement as a low cost roofing material,” Building Environment, Vol. 13, No.3, pp. 193-201 1978.

[13] M.A. Aziz, P. Paramasivam, and S.L. Lee, "Prospects for natural fibre reinforced concretes in construction,” International Journal of Cement Composites Lightweight Concrete. Vol. 3, No.2, pp. 123-154, 1981.

[14] N.C. Das Gupta, P. Paramasivam, S.L.Lee, "Mechanical properties of coir reinforced cenment pastes composites,” Housing Science, Vol. 2, No.5, pp. 391-406, 1978.

[15] N.C Das Gupta, P. Paramasivam, S.L Lee, “Coir reinforced cement pastes composites,” International Conference Proceedings of our world in concrete and structures; pp. 111-6, 1979.

[16] P. Paramasivam, G.K Nathan, and N.C.Das Gupta, "Coconut fibre reinforced corrugated slabs," International Journal of Cement Composite Lightweight Concrete, Vol. 6, No.1, pp. 19-27, 1984.

[17] V. Agopyan, H. Savastano, Jr, V.M. John, and M.A. Cincotto, "Developments on vegetable fibre-cement based materials in Sao Paula, Brazil. An overview,” Cement Concrete Compos, Vol. 27, No.5, pp. 527-533, 2005.

[18] V.M. John, M.A. Cincotto, C. Sjostrom, V. Agopyan, C.T.A. Oliveira, "Durability of slag mortar reinforced with coconut fibre," Cement Concrete Composites, Vol. 27, No. 5, pp. 5645-5719. 2005.

[19] J.P. Luisito, J.M.M. Neil, N.Rolendio, http://www.ecocoboard.net/dwnloads/Presentations\%20workshop/ Penamora: Coconut\%20fibre\%20cement\%20boards pdf:2005[accessed 02.12.20].

[20] H.B.M.H. Mohammad, "Coconut fibre reinforced wall paneling system,” Master Thesis. Faculty of Civil Engineering, University Teknologi, Malaysia: 2005.

[21] G. Ramakrishna and T. Sundararajan, "Studies on the durability of natural fibres and the effect of corroded fibres on the strength of mortar," Cement Concrete Composites, Vol 27, No. 5, pp. 575-657, 2005.

[22] Z. Li, L. Wang and X.Wang, "Flexural characteristics of coir fibre reinforced cementitious composites,” Fibre Polym, Vol., 7, No. 3, pp.286-380, 2006.

[23] J.M.L Reis, "Fracrure and flexural characterization of natural fibre -reinforced polymer concrete,” Construction Building Materials, Vol 20, No. 9, No. 3, pp. 673-681, 2006.

[24] C. Asasatjant, J. Hirunlabh, J. Khedari, S. Charoenvai, J. Seghmati, J. Khedari, S. Charoenvai, B. Zeghmati, and U.C.Shim, "Develepment of coir based lightweight cement board," Constrution Building Material, Vol. 21, No. 2, pp. 277-365, 2007.

[25] O.P.Baruah and S.A.Talukdar, “A comparative study of compressive, flexural, tensile and shear strength of concrete with fibres of different origins,” Indian Concrete Journal, Vol. 81, No. 7, pp. 17-24, 2007.

[26] Z. Li, L. Wang,and X. Wang, "Cement composites reinforced with surface modified coir fibres,” Journal of Composite Materials, Vol. 41, No. 12, pp. 1445-1502, 2007.

[27] A. Majid, L.Anthony, S. Hou, S. and C. Nawawi, "Mechanical and dynamic properties of coconut fibre reinforced concrete," Construction and Building Materials, Vol. 30, pp. 814-825, 2012.

[28] S. Spadea, I. Farina, V.P. Beradi, F. Dentale and F. Fraternalli. "Energy dissipation capacity of concrete reinforced with recycled PET Fibres’”. Ingegneria Sismica, Vol. 31 No. 2, pp. 61-70, 2014.

[29] M. Ali, "Role of post-tensioned coconut fibre ropes in mortar-free interlocking concrete construction during seismic loadings," KSCE Journal of Civil Engineering, pp. 1-8. Article in Press, 2017.

[30] W. Wang and N. Chouw, "The behavior of coconut fibre reinforced concrete (CFRC) under impact loading," Construction and Building Materials, Vol. 134, pp. 452-462, 2017.

[31] R.H., Lumingkewas, A. Husen and R. Andrianus, "Effect of fibres length and fibres content on the splitting tensile strength of coconut fibres reinforced concrete composites,”Key Engineering Materials, Vol. 748, pp. 311-315, 2017.

[32] M.I.V. Prasad, P. Saha and P.R. Kumar, "Self compacting reinforced concrete beams strengthened with natural fibre under cyclic loading” Computers and Concrete, Vol. 17, No.5, pp. 597612, 2016.

[33] BS 12; - Specification for Portland Cement. British Standards Institute, London, United Kingdom, 1996. 
[34] BS 882; - Specification for aggregates from natural sources for concrete. British Standards Institute, London United Kingdom, 1992.

[35] BS 3148; - Methods of test for water for making concrete. British Standards Institute, London, United Kingdom, 1980.

[36] BS 812-103.2 - Testing of aggregates. Method of determination of Particle size. British Standards Institute, London, United Kingdom, 1989.

[37] BS EN 12390-3; Testing hardened concrete. Compressive Strength of test Specimen. British Standards Institute, London, United Kingdom, 2006.
[38] BS EN 12390-5; Testing hardened concrete. Flexural Strength of test Specimen. British Standards Institute, London, United Kingdom, 2000.

[39] BS EN 12390-6 Testing hardened concrete. Tensile Splitting Strength of test Specimen. British Standards Institute, London, United Kingdom, 1983.

[40] BS EN 196-3- Method of Testing Cement. Determination of Setting Time and Soundness. British Standards Institute, London, United Kingdom, 1995.

[41] BS EN 12350-2; Testing of Concrete. Method for determination of slump. British Standards Institute, London, United Kingdom, 2009. 